\title{
An Assessment of Local Community Livelihood Benefits as a result of Bale Mountains National Park, Southeast Ethiopia
}

\author{
Yohannes Teshome*1, Kaba Urgessa ${ }^{2}$, Anouska Ann Kinahan ${ }^{3}$, Hailu Belay ${ }^{4}$ and Sisay Assefa ${ }^{5}$ \\ ${ }^{1}$ Jimma University College of Agriculture and Veterinary Medicine, Ethiopia \\ ${ }^{2}$ State Minister, Ministry of Agriculture and Natural Resources, Ethiopia \\ ${ }^{3}$ Research and Development TA of Bale Mountains Conservation Project, Ethiopia \\ ${ }^{4}$ Ethiopian Environment and Forest Research Institute, Ethiopia \\ ${ }^{5}$ Department of Natural Resource Management, Ethiopia
}

Submission: November 02, 2018; Published: December 12, 2018

*Corresponding author: Yohannes Teshome, Department of Natural Resources Management, Ethiopia

\section{Abstract}

Assessing and considering the potential contribution of protected areas of land on local community livelihood benefits helps to effectively protect and sustain representative samples of various biotopes. This study was designed to assess the contribution of Bale Mountains National Park (BMNP) on local community livelihood. Thirteen villages were selected purposely from five Districts and 732 households were interviewed. The survey was conducted using structured household questionnaires, focus groups discussion and key informants. Various data analysis techniques namely descriptive statistics, Chi-square $\left(x^{2}\right)$ test of independence, post hoc Tukey test after a one-way ANOVA test and Correlation (r) were used. Results showed that $76 \%$ of households earned direct benefit from the park in terms of livestock grazing $39.6 \%$ (dry season) and $37.9 \%$ (wet season), land holding $39.66 \%$, firewood collection $93.53 \%$ and grass harvesting $64.14 \%$. Ecotourism related activity $27.8 \%$, being an association member $2.1 \%$, employment (full time $0.86 \%$ and part time $0.6 \%$ ), donation $2 \%$ and training/workshop $15.5 \%$ were recorded as indirect benefit as a result of the park. Generally, it is concluded that BMNP has enormous potential to contribute on local community livelihood directly and/or indirectly, but indirect benefits remain low and a distant reality. Therefore, the management approach of the park should be changed and able to focus on offering indirect benefit opportunity equitably and reasonably for all residents living in and around the park.

Keywords: Livelihood; Benefit; Distant Reality; Local Community; Dry Season; Wet Season

\section{Introduction}

Protected area is a clearly defined geographical space, recognized, dedicated and managed, through legal or other effective means, to achieve the long-term conservation of nature with associated ecosystem services and cultural values [1]. It has usually been set aside from human exploitation and increasingly recognized its role in sustaining livelihoods of local communities [2]. Most protected areas worldwide have been established on lands owned or used by local communities that depended on the natural resources of these areas for their livelihood and as their main economic alternative [3]. However, the approach to conventional protected areas has been biased, considering the participation of local communities and nature as separate entities, and often ignoring the subsistence values for local residents [4]. And also, local community living adjacent to the park heavily depend on natural resources which derive a significant portion of livelihoods benefit [5]. Throughout the world, it is now commonplace that management of protected areas be consistent with overall socio-economic goals of local community [6]. In
Ethiopia there are 15 National Parks and fifty-eight national forest priority areas, eight wildlife reserves, four sanctuaries; eighteen controlled hunting areas and seven world heritage conservations. Evident shows that community living in and around these areas of land are highly dependent on its natural resources for their subsistence livelihood benefit which led to intensive degradations. This indicates that the contribution of protected areas on local community livelihood benefit needs to be investigated. However, this nature of investigation has not been fully done in and around BMNP. Therefore, taking this information and gap under consideration, this study was designed to assess and investigate the benefits of local community as a result of BMNP (Figure 1).

\section{Materials and Methods}

\section{Description of the study area}

Bale Mountains National Park (BMNP) is located in Southeastern Ethiopia of Oromia Regional State, between geographical coordinates of 6029'-7010' $\mathrm{N}$ and 39028'-39057' E at the distance 
of $440 \mathrm{~km}$ away from Addis Ababa. The Park was first proposed in late 1960s to protect the mountain Afroalpine habitat and the rare and endemic species of the mountain Nyala (Tragelaphus buxtoni) and the Ethiopian Wolf (Canis simensis) and finally established by the Ethiopian Wildlife Conservation Organisation in 1971 [7]. It covers an area of approximately $2,200 \mathrm{~km}^{2}$ of mountains and forest with a total population of approximately 20,000 live permanently inside the National park [8]. Mean minimum and maximum temperature range from -15 to $260 \mathrm{C}$ and its annual rainfall ranges from 1000 to $1400 \mathrm{~mm}$ respectively [9]. The boundary of the study area lies within five Districts: Adaba (West), Dinsho (North), Goba (Northeast), Dello Mena (South) and Harenna Buluk (Southwest) (Table 1).

Table1: Total number of household and sample size across the study area.

\begin{tabular}{|c|c|c|c|}
\hline District & Village & HH $\mathbf{~ ( N}_{\mathbf{0}} \mathbf{~}^{\dagger}$ & Sample size $\mathbf{( n}_{\mathbf{0}}$ ) \\
\hline Adaba & M/Darkena & 674 & 47 \\
\hline Dinsho & G/Dima & 1,403 & 98 \\
\hline & Horasoba & 760 & 53 \\
\hline & Gofingera & 607 & 43 \\
\hline & Gojera & 684 & 49 \\
\hline & Dinsho 01 & 688 & 48 \\
\hline & Karari & 861 & 60 \\
\hline & Ayida & 1,023 & 72 \\
\hline Goba & Angasso & 362 & 25 \\
\hline & Rira & 427 & 30 \\
\hline DelloMena & Shedem & 563 & 39 \\
\hline Harenna & Chiri & 1,389 & 97 \\
\hline 5 & Hawo & 1,020 & 71 \\
\hline
\end{tabular}

\section{Data collection}

From five Districts, 13 villages were selected purposely, and 732 households were interviewed. To address the study issue, both qualitative and quantitative data were collected. Focus Groups Discussion (FGD) and Key Informant (KI) interview were also used to strengthen the result. The minimum sample size required, for a very large population $(\mathrm{N}>10,000)$ was determined by using sample size determination formula (7).

$$
n_{o}=\frac{n N_{o}}{N}
$$

\section{Where:}

$\mathrm{n}=$ total sample size

$\mathrm{P}=$ prevalence rate for the population $(0.5)$

$\mathrm{d}=$ margin/precision of sampling error tolerated

$\mathrm{Z}=\mathrm{z}$ statistic for a level of confidence

Therefore, the sample estimate at $95 \%$ of confidence interval (CI) and prevalence value of ( $\mathrm{P}=0.5)$ at a precision (d) of 0.036 for the total size of 10,461 households in a sample frame provided a sample size of 732 households. Finally, in order to determine the sample size of households for each representative village the total sample sizes of the study were allocated for each representative Villages.

$n=\frac{\left(Z_{1-\alpha / 2}\right)^{2} P(1-P)}{d^{2}}$

Where:

$\mathrm{n}_{\mathrm{o}}=$ sample size for a single Village

$\mathrm{n}=$ total sample size for the study

$\mathrm{N}_{\mathrm{o}}=$ number of households in a single Village

$\mathrm{N}=$ total size of households across the Village

After determined the sample size in every Village, sampling fraction method were applied to select those representative respondents from the list. The sampling fraction method which is symbolized by $\mathrm{K}$, the samples was drawn from the total number of households in a single Village on the basis of the sampling fraction ( $\mathrm{K}^{\text {th }}$ households) that is equal to No/no.

\section{Data analysis}

Data from the household questioners was coded and run to Statistical Package for Social Science (SPSS) version 19 and analysed using descriptive statistics and responses compared using chi-square $\left(\chi^{2}\right)$ tests of independence. Post hoc Tukey test were used to identify the real difference after a one-way ANOVA test. Correlation ( $\mathrm{r}$ ) was also used to determine the variable relationship. The information collected from FGD and KI was summarized using a text analysis method and presented in a description way.

\section{Result and Discussion}

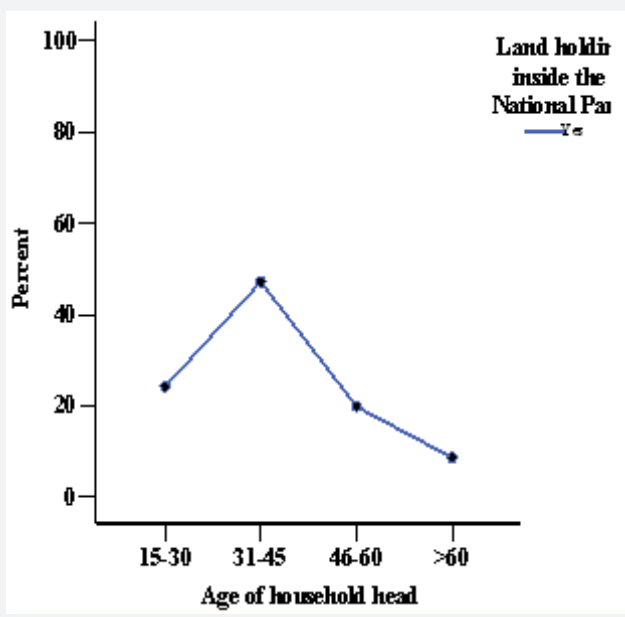

Figure 1: Age of household head and land holding inside the BMNP.

Of the total 732 respondents, 21 who could not replay accurately, and outliers were removed from the analysis and it becomes 711. Out of these $612(86 \%)$ were males and 99 
(14\%) females. The majority $(44.6 \%)$ of the respondents' age has ranged from 31 to 45 , while $23.2 \%, 22.5 \%$ and $9.7 \%$ of the respondents were less than 30 , greater than 45 and older than 60 years, respectively. Out of the total respondents, most (71.9\%) were monogamous and the rest $25.2 \%, 2.3 \%, 0.4 \%$ and $0.3 \%$ were polygamy, single, divorced and widowed, respectively. The result indicates that family size across the area varied between 2 and 16 persons with an average of 9 persons. This is explained by the polygamy marriage system which is $25.2 \%$. Household size is higher, compared to Guassa community conservation area; family size was estimated at the range of 4-6 persons [10]. Household size in the study area is also much higher than the National average of 4.8 and higher than 4.9 persons for most rural areas in Ethiopia [11]. Logically, large households require more resources to meet their livelihood needs; this increases demand for resources.
Large families struggle with available livelihood benefit [12], but families with a large proportion of working members can pool livelihood benefit to increase household income. With this regard, most respondents living across the study area were perceived as they have been benefited from large family size for labour availability. Accordingly, it will also increase the pressure on resources since most rural people living in and around the BMNP have few alternative means of livelihood. The results showed that, $81.4 \%$ of the households were living inside and/or nearby the park for more than 20 years and it was the place where they were born, and their family lived (81.6\%) (Table 2). Statically, there is a significant difference in the duration of respondent's household living in and around the National Park $\left(\chi^{2}=1.714, \mathrm{df}=4, \mathrm{P}<0.01\right)$ and the reason why they decide to live there $\left(\chi^{2}=2.651, \mathrm{df}=4, \mathrm{P}\right.$ $<0.01$ ) (Figure 1).

Table 2: The Total Years of Respondent Placement in And Around BMNP.

\begin{tabular}{|c|c|c|c|c|c|c|}
\hline Characteristic & Year & $\mathbf{N}$ & $\%$ & $\chi^{2}$ & df & P-Value \\
\hline \multirow{5}{*}{ HH living in and around BMNP } & $1-5$ & 5 & 0.7 & 1.714 & 4 & 0.001 \\
\hline & $6-10$ & 12 & 1.7 & & & \\
\hline & $11-15$ & 20 & 2.8 & & & \\
\hline & $16-20$ & 95 & 13.4 & & & \\
\hline & $>20$ year & 579 & 81.4 & & & \\
\hline \multirow{5}{*}{$\begin{array}{l}\text { The reason why HHs decided to live in } \\
\text { and around BMNP }\end{array}$} & Close to park & 30 & 7.9 & 2.65 & 4 & 0.001 \\
\hline & Lack of land in another place & 58 & 8.2 & & & \\
\hline & Cultural reason & 4 & 0.5 & & & \\
\hline & Employment & 13 & 1.8 & & & \\
\hline & A place where they born, and their family lived & 580 & 81.6 & & & \\
\hline
\end{tabular}

\section{A general over view of livelihood activities}

Table 3 provides a simplified summary of the diversity of household livelihood activities across the villages, showing which activities are the most important for contributing to their family needs. Therefore, from the result, most respondent households depended on crop production $(68.7 \%)$ for subsistence, while $22.9 \%$ depended on animal production and the balance engaged in both activities. Off-farm activities were also accounted for $32.7 \%$ of livelihood benefit. Livelihoods activities involve increasing diverse portfolio by an individual or household in order to survive and improve the living standard [13].

Table 3: Summary of Respondent's Livelihood Activities Across the Study Area.

\begin{tabular}{|c|c|c|c|c|c|c|c|}
\hline \multirow{2}{*}{ Village } & \multirow{2}{*}{ Crop production } & \multirow{2}{*}{ Animal production } & \multicolumn{5}{|c|}{$\%$ Off/non-farm } \\
\hline & & & Employment & Bamboo & Beekeeping & Forest product & Other \\
\hline Meskel & 88.4 & 11.6 & - & - & - & - & - \\
\hline Geremba & 61.5 & 31.3 & 3.1 & - & - & - & 4.2 \\
\hline Soba & 80.8 & 17.3 & - & - & - & - & 1.9 \\
\hline Gofingira & 85.0 & 15.0 & - & - & - & - & - \\
\hline Gojara & 71.7 & 28.3 & - & - & - & - & - \\
\hline Dinsho 01 & 37.5 & 2.1 & 8.3 & - & - & 4.2 & 47.9 \\
\hline Karari & 76.7 & 21.7 & - & - & - & - & 1.7 \\
\hline Ayida & 27.1 & 70.0 & - & - & - & - & 2.9 \\
\hline Shedem & 57.9 & 26.3 & - & 10.5 & 5.3 & - & - \\
\hline Angasso & 76.0 & 20.0 & - & - & - & - & 4.0 \\
\hline Rira & 73.3 & 20.0 & - & - & - & - & 6.7 \\
\hline Chiri & 86.2 & 8.5 & 1.1 & - & - & - & 4.3 \\
\hline
\end{tabular}




\section{International Journal of Environmental Sciences \& Natural Resources}

\begin{tabular}{|c|c|c|c|c|c|c|c|}
\hline Hawo & 71.0 & 26.1 & - & - & - & - & 2.9 \\
\hline Total & 893.1 & 298.2 & 12.5 & 10.5 & 5.3 & 4.2 & 76.5 \\
\hline Average & 68.7 & 22.9 & 4.2 & 10.5 & 5.3 & 4.2 & 8.5 \\
\hline
\end{tabular}

\section{Local Community benefits as a result of BMNP}

Focus group discussion and key informants across each village have generated mixed responses about perceived benefits as a result of park, with half of the group agreed in some villages that park was beneficial in general while the other half has disagreed. According to them, the presence of some developmental projects and the building-up of infrastructure (only school in specific

Table 4: Local community direct benefit as a result of BMNP.

\begin{tabular}{|c|c|c|c|c|c|}
\hline Characteristic & $\mathbf{N}$ & $\%$ & $\chi^{2}$ & df & P-Value \\
\hline Direct benefit from the park & 541 & 76 & 69.385 & 12 & 0.000 \\
\hline From land holding inside the park & 282 & 39.66 & 92.654 & 12 & 0.000 \\
\hline From livestock grazing during dry season & 266 & 39.6 & 89.936 & 12 & 0.000 \\
\hline From livestock grazing during wet season & 254 & 37.9 & 104.021 & 12 & 0.000 \\
\hline From firewood collection inside the park & 665 & 93.53 & 73.437 & 12 & 0.094 \\
\hline From grass harvesting inside the park & 456 & 64.14 & 88.688 & 12 & 0.000 \\
\hline
\end{tabular}

\section{Direct benefits}

Of the total, $76 \%$ of respondent households perceived getting direct benefits from the BMNP in terms of land holding (39.7\%), livestock grazing (39.6\% (dry season) and 37.9\% (wet season), firewood collection (93.53\%) and grass harvesting (64.14\%). However, the magnitudes of direct livelihood benefit from the park resources were significantly different $\left(\chi^{2}=69.385, \mathrm{df}=12\right.$, $\mathrm{P}<0.001$ ) among the villages (Table 4). This means that the type and scale of direct benefit from the park were vary from village to village. For instance, households living closer to the park boundary or living fully inside the park had a significant benefit from all-natural resource of the park.

\section{Land holding}

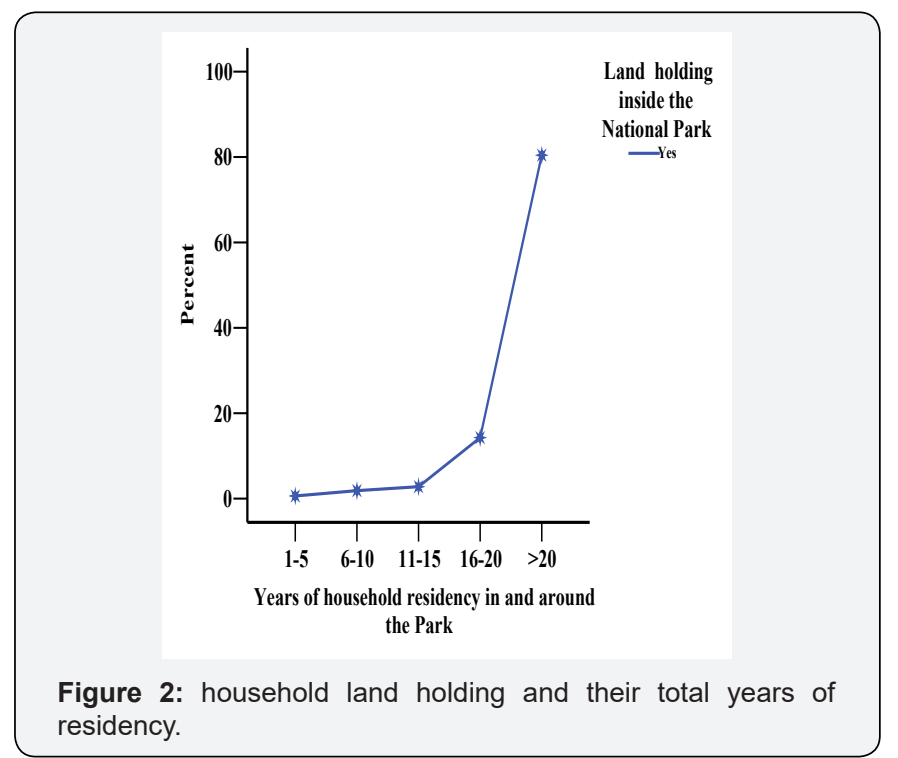

Figure 2: household land holding and their total years of residency. village) were perceived as indirect and direct benefits as a result of the park. Among the indirect benefit reported across the study area were ecotourism related activity, full/part time employment, donation and training and among direct benefits reported were grazing livestock, land holding, firewood collection and grass harvesting. On the other hand, some participant appreciated the existence of the park because of the possibility for their children to see wild animals and direct benefit from the park resources.
Across the study area, there was a lot of fragmentation of land most households reporting having more than one parcels of land inside and/or adjacent to the park. However, it was not the main scope of this study to investigate the impacts of any fragmentation on the park. Fragmentation is due to the trend and practice of inheritance whereby the family head allocates land among his family. When the family head stays longer in and adjacent to the park and the size of his family become big and bigger, each member of the family inherits a small portion of land and may have a chance to delineate by his own clearance more land. There is usually a relationship between the age of the household head and total years of residency in and adjacent to the park with the side of land holding inside the park. In this study also, there was an association between the age of the family head ( $r=0.05)$, the total years of household's residency in and around the park $(\mathrm{r}=0.01)$ and land holding inside the Park. For instance, households head in the age interval of 31-45 years have possessed more land inside the park, compared to the other (Figure 2). At the same time, 
households with ( $>20$ ) years of residency in and around the park area have possessed more land inside the park, compared to the other (Figure 3).

The result from a focus group discussion and key informant interview clearly indicates that having land inside the BMNP is the primary essential resources by which one of the livelihood benefits of the local community linked to the park. Statically, there were significant differences $\left(\chi^{2}=92.654, \mathrm{df}=12, \mathrm{P}<0.001\right)$ in land holding inside the park among the villages. For instance, respondent households living in Rira and Chiri villages had significantly more land inside the park, followed by Ayida and Hawo (Figure 4) Rira village was fully situated inside the park compared to other villages which can explain why they hold and possessed more land. However, Tukey test showed no significant difference when Rira compared with Chiri $(\mathrm{P}=0.75)$, Ayida $(\mathrm{P}=1)$ and Hawo $(\mathrm{P}=0.975)$ in land holding inside the park. Mostly these villages were located inside or more proximate to the park administrative boundary. As a result, households living in these villages have hold and possessed better direct benefits from land inside the park, compared to another village.

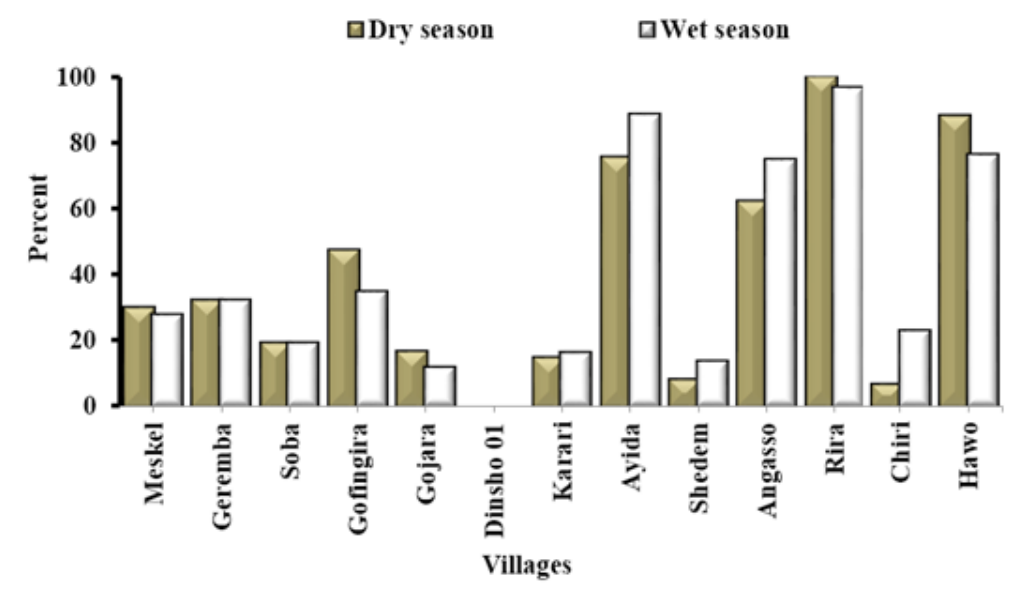

Figure 4: A comparison of local community benefits from livestock grazing inside the Park during both seasons.

\section{Livestock grazing}

Most of the time, local communities admit their livestock in and around the park to meet their livelihood needs. As already discussed earlier, of the total $22.9 \%$ of respondents were dependent on animal production. As a result, these households have benefited from livestock grazing inside the park during wet and dry season $39.6 \%$ and $37.9 \%$, respectively. This resulted in respondent households suggesting that the main livestock production related problem across the study area was due to conflict with the park over grazing (35\%). Both, key informants and focus group discussion also revealed that, the park serve as a main feed source to their livestock's especially during dry season where there is a shortage of feed on their farm and communal grazing land. This was also cited by some studies done in the same area. For instance, admission of livestock into the BMNP area have increased with time; livestock enter to use the high-altitude mineral springs and remain in the area for much longer periods than they used to, taking benefit of the sparse grazing obtainable in the delicate Afro alpine vegetation belt $(15,4,11$ and 12). As could be seen above Figure 5, respondent households living in four villages namely Rira, Ayida, Hawo and Angasso had significantly benefited from livestock grazing inside the park during both seasons, compared to other villages. Villages differed significantly in benefits in terms of livestock grazing during dry season $\left(\chi^{2}=\right.$ 89.936, $\mathrm{df}=12, \mathrm{P}<0.001)$ and wet season $\left(\chi^{2}=104.021, \mathrm{df}=\right.$ $12, \mathrm{P}<0.001$ ) inside the park Table 4 above. On the other hand,
Tukey test showed no significant difference when Rira compared with Ayida $(\mathrm{P}=0.894)$, Hawo $(\mathrm{P}=0.975)$ and Angasso $(\mathrm{P}=0.676)$ in livestock grazing inside park during dry season. At the same time, the same test showed no significant difference when Rira compared with Ayida $(\mathrm{P}=1)$, Hawo $(\mathrm{P}=0.998)$ and Angasso $(\mathrm{P}=0.986)$ in livestock grazing inside park during wet season. As already mentioned before, Dinsho 01 village were located next to the administration office of the park, this resulted ease for scouts to control the community's livestock not to graze inside the park during both seasons. As a result, as could be seen from Figure 5, Dinsho 01 village has not possessed benefit from livestock grazing inside the park during both seasons [14-16].

\section{Firewood collection}

In cross-examined result of the study, local communities living in and around the park, firewood is the primary (often the dominant) source of fuel for domestic use that was mostly collected from the park (93.53\%). It is very clear that forests are particularly targeted by communities who have few other alternatives, and therefore have to rely on forests as a life support system. The result of this study also indicates that, respondent households living across the study area were recorded as having fewer alternative sources of fuel for domestic use, and lower alternative source of livelihood benefit, exhibited greater levels of dependency on park forest resources. With this regard, with the exception of Dinsho 01, there was no significant difference observed among the villages $\left(\chi^{2}=73.437, \mathrm{df}=12, \mathrm{P}=0.094\right)$ in the 
benefits obtained from firewood collection inside the park Table 4 above. This means that all villages were possessed benefit from the park forest resource for their firewood needs. But households living in Dinsho 01 had possessed the lower benefit from firewood collection inside the park, compared to other households living in the other villages. Tukey test also showed a significant difference when Dinsho 01 compared with other villages in firewood collection inside park. During data collection process across the villages, trees were unfairly axed for pole and firewood and chopped into strips and then arranged for domestic use as well as for local market (District) on an average of two days per week. During the same process, there was no clearly identified evidence that the respondents collected and used a dead wood for their benefit. Accordingly, the study also found evidence that wood extraction may have resulted in the forest structure observed, where larger trees were largely absent especially in Shedem, Rira and Hawo villages. Therefore, the survey of assessing the local community direct livelihood benefit from firewood collection inside the park implies that, the park is directly benefiting the community living in and around its administration zone. As long as directly benefiting the local community, the amount and frequency of tree axing and chopping was a testament for dynamic deforestation of the park $[17,18]$.

\section{Grass harvesting}

Most respondent households living across the study area were constructing their house by using locally available materials, for instance, grass for roof top. Of the total; $64.14 \%$ of respondent households have possessed benefit from harvesting grass inside the park. All villages but in different scale had possessed benefit from grass harvesting inside the park. Villages has differed significantly $\left(\chi^{2}=88.688, \mathrm{df}=12, \mathrm{P}<0.001\right)$ in terms of benefit from grass harvesting inside the park Table 4 above. The comparisons also show, respondent households living in Gojara, Karari and Ayida had possessed small percentage of benefit from grass harvesting, compared to the rest villages. On the other hand, Rira village respondents had significantly more benefited from grass harvesting inside the National Park, compared to the rest villages. Tukey test also showed no significant difference when Rira compared with Ayida $(\mathrm{P}=1)$, Gojara $(\mathrm{P}=1)$ and Karari $(\mathrm{P}=0.990)$ in benefits from grass harvesting inside the National Park (Appendix 5). In fact, households living more proximate to infrastructure development (road) and another important source of livelihood than crop production has an iron-sheet roof top.

\section{Indirect benefits}

The finding indicates that, of the total, $40.9 \%$ of respondents were realized ecotourism and its related activity in their villages as a result of the park existence. However, having these natures of activity as results of the National park is not surprising. The question was its distribution and positive and/or negative impacts on villagers. For instance, the people who reported being very close to the park headquarters were acknowledging benefit from ecotourism and its related activity such as; tourist guides, horse rent and selling some local handcraft for tourists. Focus group discussion and key informant result also indicates that being close to the park administration zone and members of local association are believed to be being a beneficial as a result of the park. However, the study revealed that, of the total respondent only 2.1\% households living in Dinsho 01, Karari, Gojara and Gofingira Villages were benefited from being an association member that organized by BMNP. A multiple comparison test also shows that respondent households' living in Dinsho 01 had significantly more benefited from these options, compared to other Villages. Table 5 shows a summary of local community employment benefit as a result of BMNP and its partner organizations. Out of the total sampled households living across the study area only $0.86 \%$ and $0.6 \%$ were benefited from full and part time employment respectively. Results further showed that full time employment opportunities for local community were mainly offered by EWCP, BMNP and FZS $66.6 \%, 16.7 \%$ and $16.7 \%$, respectively. The same results indicate that part time employment opportunities for local community were offered by only BMNP (75\%) and MELCA (25\%) (Table 5).

Table 5: Local community employment benefit as a result of BMNP existence.

\begin{tabular}{|c|c|c|c|c|c|c|}
\hline Characteristic & Organizations & $\mathbf{N}$ & $\%$ & $\chi^{2}$ & df & P-Value \\
\hline \multirow{3}{*}{ Full time employment } & BMNP & 1 & 16.7 & \multirow{3}{*}{3.000} & \multirow{3}{*}{2} & \multirow{3}{*}{0.223} \\
\hline & FZS & 1 & 16.7 & & & \\
\hline & EWCP & 4 & 66.6 & & & \\
\hline \multirow{2}{*}{ Part time employment } & BMNP & 3 & 75 & \multirow{2}{*}{1} & \multirow{2}{*}{1} & \multirow{2}{*}{0.014} \\
\hline & MELCA & 1 & 25 & & & \\
\hline \multicolumn{2}{|c|}{ Category } & SS & df & MS & $\mathbf{F}$ & Sig. \\
\hline \multirow[t]{3}{*}{ Full time employment } & Between Groups & 0.287 & 12 & 0.024 & 2.947 & 0.001 \\
\hline & Within Groups & 5.663 & 698 & 0.008 & & \\
\hline & Total & 5.949 & 710 & & & \\
\hline \multirow[t]{2}{*}{ Part time employment } & Between Groups & 0.138 & 12 & 0.011 & 2.089 & 0.016 \\
\hline & Within Groups & 3.840 & 698 & 0.006 & & \\
\hline \multicolumn{2}{|c|}{ Total } & 3.977 & 710 & & & \\
\hline
\end{tabular}




\section{International Journal of Environmental Sciences \& Natural Resources}

Table 6: A test summary of donation and training / workshop as a result of the Park and its partners.

\begin{tabular}{|c|c|c|c|c|c|c|}
\hline Characteristic & \multicolumn{2}{|c|}{ Organizations } & $\%$ & $\chi^{2}$ & df & P-Value \\
\hline \multirow{3}{*}{ Donation } & \multicolumn{2}{|c|}{ BMNP } & 43 & \multirow{3}{*}{2.738} & \multirow{3}{*}{2} & \multirow{3}{*}{0.254} \\
\hline & \multicolumn{2}{|c|}{ FZS } & 36 & & & \\
\hline & \multicolumn{2}{|c|}{ SOS FARM } & 21 & & & \\
\hline \multirow{5}{*}{ Trainer } & \multicolumn{2}{|c|}{ BMNP } & 49 & & & \\
\hline & \multicolumn{2}{|c|}{ FZS } & 15 & & & \\
\hline & \multicolumn{2}{|c|}{ EWCP } & 4 & 55.971 & 4 & 0.000 \\
\hline & \multicolumn{2}{|c|}{ MELCA } & 5 & & & \\
\hline & \multicolumn{2}{|c|}{ SOS-FARM } & 27 & & & \\
\hline \multicolumn{2}{|c|}{ Category } & SS & df & MS & $\mathbf{F}$ & Sig. \\
\hline \multirow[t]{3}{*}{ Donation } & Between Groups & 0.413 & 12 & 0.034 & 1.805 & 0.044 \\
\hline & Within Groups & 13.311 & 698 & 0.019 & & \\
\hline & Total & 13.724 & 710 & & & \\
\hline \multirow[t]{3}{*}{ Training } & Between Groups & 2.768 & 12 & 0.231 & 1.734 & 0.046 \\
\hline & Within Groups & 92.827 & 698 & 0.133 & & \\
\hline & Total & 95.595 & 710 & & & \\
\hline
\end{tabular}

There was a significant difference among villages in benefiting from full time employment $(\mathrm{F} 2.947, \mathrm{df}=12, \mathrm{P}=0.001)$ and part time employment $(\mathrm{F} 2.089, \mathrm{df}=12, \mathrm{P}=0.016)$ as a result of BMNP and its partner organizations. The summary of community's benefits in terms of donations and training/workshop as a result of the BMNP and its partner organizations existence also summarized in Table 6 below. The result revealed only 2\% ( $=14)$ of households had benefited from donations that was offered by BMNP (43\%, N=6), FZS (36\%, N=5) and SOS FARM (21\%, N=3). The importance of training/workshop for local communities living in and/or adjacent to the protected areas is acknowledged by several studies. According to BMNP-GMP (2007), effective community development can be done by providing training and start-up conditions for local communities to establish their own small-loan schemes. However, the result of this study indicates that only small number of households living in and around BMNP trained or attended on workshops that was provided by BMNP (49\%), FZS (15\%), EWCP (4\%), MELCA (5\%) and SOS-FARM (27\%) (Table 6). As indicated on the table above, there was significant difference between villages in benefits from donation (F1.805, $\mathrm{df}=12, \mathrm{P}=0.044$ ) as a result of the BMNP and its partner organizations. With the exception of few, most respondent households living across the Villages were not benefited from donation and organizations are also not equally distributed at all community level, if any found. With this regard, organization were not differed ( $\chi 2=2.738, \mathrm{df}=2, \mathrm{P}=0.254$ ) in offering donation across different Villages.

\section{Conclusion}

From the general finding of the study it is safe to conclude that, Bale Mountains National Park (BMNP) has a potential to contribute on the local community livelihood benefit directly and/ or indirectly but indirect benefits remain low and a distant reality.
Apart from having no a good management system, equitably and reasonably distributed indirect benefit options as a result of the park existence, the costs associated with the park resources such as wild animal are having a serious duty and problem only for local community. As a result, the management approaches of the park are not satisfactory for communities living in and around the administration zone of the park, but less appreciation of the manner in which ecotourism related activities.

\section{References}

1. Adams W, Aveling R, Brockington D, Dickson B, Elliott J, et al. (2004) Biodiversity Conservation and the Eradication of Poverty Science 306 (56): 1146-1149.

2. Allendorf T, Swe K, Oo T, Htut Y, Aung M, et al. (2006) Community attitude toward three protected areas in upper Myanmar (Burma) Environmental Conservation 33(4):344-352.

3. BMNP (2007) Bale Mountains National Park: General Management Plan 2007-2017. BMNP with Frankfurt Zoological Society, Ethiopia. Management Plan 176 (20): 19-20.

4. Brown L (1966) A report on the National Geographic Society/World Wildlife Fund Expedition to study the Mountain Nyala Tragelaphus buxtoni. Nairobi Mimeo pp. 118.

5. (2007) Central Statistical Agency (Ethiopia). Federal democratic republic of Ethiopia.

6. Charnley S, Fischer A, Jones E (2007) Integrating traditional and local ecological knowledge into forest biodiversity conservation in the Pacific Northwest. Forest Ecology and Management p. 14-28.

7. Daniel W (1999) Biostatistics: A Foundation for Analysis in the Health Sciences. 7th edition New York: John Wiley and Sons USA.

8. Ellis F (2000) Rural livelihoods and diversity in developing countries. Oxford, Oxford University Press.

9. Engedasew A (2010) Human and wildlife conflict involving Ethiopian wolf (canis simensis) and gelada baboon (Theropithicus gelada) in and around Guassa Community Conservations area, north shoa, An MSc 
Thesis presented to the School of Graduate Studies of Addis Ababa University 100(43)

10. Frankfurt Zoological Society (FZS) (2007) Assessments of settlement in and around the Bale Mountains National Park. Bale, Ethiopia. (Unpublished project document).

11. Hillman J (1986) Bale Mountains National Park: Management Plan Wildlife Conservation Organization, Addis Ababa pp. 250.

12. Hillman J (1993) Ethiopia Compendium of Wildlife Conservation Information. New York Zoological Society and Ethiopian Wildlife Conservation Organization, Addis Ababa.

13. Lu Y, Chen L, Fu B, Liu S (2003) A framework for evaluating the effectiveness of protected areas: the case of Wolong Biosphere Reserve. Lands Urban Planning 63(4): 213-223.
14. Mamo G, Sjaastad E, Vedeld P (2007) Economic dependence on forest resources: A case from Dendi District, Ethiopia. Forest Policy and Economics 9 (8): 916-927.

15. Mooney H (1963) An account of two journeys to the Haraenna Mountains in Bale Province, southeast Ethiopia, 1958 and 1959-60. Proc Linn Soc 172: 127-147.

16. Plumptre A, Kayitare A, Rainer H, Gray M, Munanura I, et al. (2004) The Socio economic Status of People Living Near Protected Areas in the Central Albertine Rift. Albertine Rift Technical Reports pp. 127.

17. Sillero C (1994) Behavioral Ecology of Ethiopian Wolf D Phil. Thesis, University of Oxford.

18. UNEP (1995) Global Biodiversity assessment published for the United Nations Environmental Program pp. 552-574.

Your next submission with Juniper Publishers will reach you the below assets

- Quality Editorial service

- Swift Peer Review

- Reprints availability

- E-prints Service

- Manuscript Podcast for convenient understanding

- Global attainment for your research

- Manuscript accessibility in different formats

( Pdf, E-pub, Full Text, Audio)

- Unceasing customer service

Track the below URL for one-step submission https://juniperpublishers.com/online-submission.php 